\title{
4. How do internships undertaken during higher education affect graduates' labour market outcomes in Italy and the United Kingdom? ${ }^{1}$
}

\author{
Charikleia Tzanakou, Luca Cattani, Daria \\ Luchinskaya and Giulio Pedrini
}

\subsection{INTRODUCTION}

In the past two decades, education-to-work transitions for young people have become more turbulent and uncertain. The role of work experience and, more specifically, internships during higher education (HE) in facilitating access to work and enhancing labour-market outcomes has been debated in academic and policy literature. ${ }^{2}$ For HE students, internships are widely considered a way of accessing work experience and on-the-job training, and are assumed to enhance their labour-market outcomes, in particular at the early career stage. For example, almost half (46 per cent) of 18- to 35-year-olds in the EU27 reported having undertaken an internship at some time in their

1 We would like to thank the editors and symposium participants for their constructive comments and editorial assistance, our colleagues (especially Professor Marina Timoteo, Dr Silvia Ghiselli, Dr Dorel Manitiu and Professor Kate Purcell for access to AlmaLaurea and Futuretrack data), and IAS Warwick for funding this collaborative work.

2 Angus Holford, 'Access to and Returns from Unpaid Graduate Internships' (2017) ISER Working Paper Series 2017-07, https://www.iser.essex.ac.uk/research/ publications/working-papers/iser/2017-07, accessed 30 March 2021; Carys Roberts, The Inbetweeners: The New Role of Internships in the Graduate Labour Market (Institute for Public Policy Research 2017), https://www.ippr.org/publications/the -inbetweeners, accessed 30 March 2021; Felix Weiss, Markus Klein and Thomas Grauenhorst, 'The Effects of Work Experience during Higher Education on Labour Market Entry: Learning by Doing or an Entry Ticket?' (2014) 28 Work, Empl \& Soc 788. 
life, ${ }^{3}$ with younger cohorts experiencing a higher prevalence of internships than older cohorts, suggesting that internships are becoming more common. ${ }^{4}$ Nevertheless, not everyone benefits equally, and different types of internships may be associated with different types of outcomes. ${ }^{5}$

While there is no single fixed definition of internships, in this chapter we follow Broek and others, ${ }^{6}$ in alignment with other studies, ${ }^{7}$ by distinguishing between: (1) internships undertaken as part of vocational/academic curricula; (2) internships associated with active labour-market policies; and (3) internships in the open market. In contrast to Chapter 6 in this volume, which focuses on internships after graduation from HE, we focus on curricular and open-market internships taking place during HE studies in the first cycle (bachelor level) of the Bologna Process.

We explore how these internships affect graduates' transitions to work in the UK and Italy, countries in which the incidence of internships during HE study used to be lower than in other European countries, ${ }^{8}$ but has increased over time. ${ }^{9}$ This expansion highlights the increasing importance of internships undertaken during HE for enabling a smoother transition to the labour market and for mitigating the risk of high-skilled workers moving down the

3 European Commission, 'Eurobarometer 80.1 (2013)' (2017) TNS opinion, GESIS Data Archive, ZA5876 Data file Version 2.0.0, https://doi.org/10.4232/1.12768, accessed 30 March 2021.

4 Simon Broek, Terence Hogarth, Liga Baltina and Amerigo Lombardi, Skills Development and Employment: Apprenticeships, Internships and Volunteering (European Parliament 2017), http://www.europarl.europa.eu/RegData/etudes/STUD/ 2017/602056/IPOL_STU(2017)602056_EN.pdf, accessed 30 March 2021.

5 Ann-Marie Bathmaker, Nicola Ingram and Richard Waller, 'Higher Education, Social Class and the Mobilisation of Capitals: Recognising and Playing the Game' (2013) 34 Brit J Sociol Educ 723; Carl Cullinane and Rebecca Montacute, Pay As You Go? Internship Pay, Quality and Access in the Graduate Jobs Market (Sutton Trust 2018).

6 Broek and others (n 4) 16.

7 Eg Andrew Stewart, Rosemary Owens, Anne Hewitt and Irene Nikoloudakis, 'The Regulation of Internships: A Comparative Study' (2018) ILO Employment Policy Department Working Paper No 240.

8 Jim Allen and Rolf Van der Velden (eds), The Flexible Professional in the Knowledge Society: New Challenges for Higher Education (Springer Science \& Business Media 2011).

9 Holford (n 2); Andrea Cammelli, Gilberto Antonelli, Furio Camillo, Angelo di Francia, Silvia Ghiselli and Matteo Sgarzi, 'Graduates' Employment and Employability after the "Bologna Process" Reform: Evidence from the Italian Experience and Methodological Issues' (2011) AlmaLaurea Inter-University Consortium Working Paper No 1. 
occupation ladder. ${ }^{10}$ In both countries, the connection between $\mathrm{HE}$ and the labour market is relatively loose in that the field of study does not strongly determine routes into occupations and professions, ${ }^{11}$ although this linkage may be stronger in Italy than in the UK. The two countries also have different institutional arrangements, with the UK often viewed as an example of a liberal, and Italy of a conservative and corporatist, welfare state, ${ }^{12}$ although Italy may have moved towards more liberal arrangements on some dimensions in recent years. ${ }^{13}$ Both countries are also more liberal than other European countries in their regulation of internships undertaken during HE. Thus, Italy and the UK provide an interesting comparison of internships and their characteristics in national institutional and regulatory contexts. In Italy, curricular internships are widely considered first as training, while in the UK most types of internships tend to be seen first as work experience. ${ }^{14}$ This leads us to ask: does undertaking internships during HE lead to different early career outcomes for graduates in the UK and Italy, and if so why?

10 Pal Beaudry, David Green and Benjamin Sand, 'The Great Reversal in the Demand for Skill and Cognitive Tasks' (2016) 34(S1) J Lab Econ S199.

11 Arthur Lore and Brenda Little, The REFLEX Study: Exploring Graduates' Views on the Relationship Between Higher Education and Employment (Centre for Higher Education Research and Information, Open University 2010); Brenda Little, 'Reading Between the Lines of Graduate Employment' (2001) 7 Qual Higher Educ 121; Antonio Schizzerotto and Carlo Barone, Sociologia dell'istruzione (Il Mulin 2006), cited in Valentina Di Stasio, 'Education as a Signal of Trainability: Results from a Vignette Study with Italian Employers' (2014) 30 Eur Sociol Rev 796.

12 Gøsta Esping-Andersen, The Three Worlds of Welfare Capitalism (Princeton University Press 1990). Other authors define Italy as a 'mixed-market economy' characterized by low levels of social protection and a high level of employment protection: Oscar Molina and Martin Rhodes, 'The Political Economy of Adjustment in Mixed Market Economies: A Study of Spain and Italy' in Bob Hancké, Martin Rhodes and Mark Thatcher (eds), Beyond Varieties of Capitalism: Conflict, Contradictions, and Complementarities in the European Economy (Oxford University Press 2007).

13 Lyle Scruggs and James Allan, 'Social Stratification and Welfare Regimes for the Twenty-First Century: Revisiting "The Three Worlds of Welfare Capitalism", (2008) 60 World Politics 642; Marc Goergen, Chris Brewster, Geoffrey Wood and Alan Wilkinson, 'Varieties of Capitalism and Investments in Human Capital' (2012) 51 Indust Rel 501.

14 See eg for the UK: 'An internship is a great way to gain experience and discover what a particular role is like': Prospects, 'Work Experience and Internships' (2020), https://www.prospects.ac.uk/jobs-and-work-experience/work-experience-and -internships, accessed 30 March 2021. For Italy: 'An internship is a period of on-the-job training that gives students and recent graduates the opportunity to acquire professional skills and know-how transferable to the world of work and to gain experience of a real work environment': Ca' Foscari University of Venice, 'Internships in Italy' (2020), https://www.unive.it/pag/17134/, accessed 30 March 2021. 
The remainder of this chapter is structured as follows: first, we give a brief overview of research on internships. Then, we outline the surrounding HE and labour-market contexts in the UK and Italy. After explaining the methodological approach used (datasets, samples and empirical strategies), we present our results. The final section discusses the implications of our results and ends with key recommendations for regulating internships undertaken during HE.

\subsection{INTERNSHIPS AND EARLY EMPLOYMENT OUTCOMES: THEORETICAL FRAMEWORK AND EXISTING EVIDENCE IN ITALY AND THE UK}

There are several key theoretical reasons why we might expect internships to affect labour-market outcomes. We focus on two main theoretical perspectives: human capital and signalling/screening. From the human capital perspective, the typical insight is that learning is earning: ${ }^{15}$ undertaking an internship, as for other forms of workplace training, leads to skill development, which leads to improved productivity and, in turn, to higher wages. ${ }^{16} \mathrm{We}$ may also interpret the human capital insight more broadly, and consider that the skills developed during an internship make a candidate more employable than someone with similar educational experience but no internship. The broad implications of this perspective are that all internships should improve labour-market outcomes.

In contrast, from the signalling/screening perspective, ${ }^{17}$ internships do not necessarily need to lead to skill development (although they may do so). Instead, internships act as information to differentiate between graduates entering the labour market, which is deemed to be increasingly important when educational credentials inflate. ${ }^{18}$ For example, internships might improve employment prospects because job seekers use them to signal their general abilities and learning potential to employers (who are unable to observe applicants' ability directly). From the related job-queue perspective, job seekers can

15 Gary Becker, Human Capital: A Theoretical and Empirical Analysis, with Special Reference to Education (2nd edn, Columbia University Press 1964); Claire Smetherham, 'Firsts among Equals? Evidence on the Contemporary Relationship between Educational Credentials and the Occupational Structure' (2006) 19 J Educ \& Work 29.

${ }_{16}$ Eg Philip O'Connell and Delma Byrne, 'The Determinants and Effects of Training at Work: Bringing the Workplace Back In' (2012) 28 Eur Sociol Rev 283.

17 Michael Spence, 'Job Market Signalling' (1973) 87 Quart J Econ 355.

18 Phillip Brown, 'Cultural Capital and Social Exclusion: Some Observations on Recent Trends in Education, Employment and the Labour Market' (1995) 9 Work, Empl \& Soc 29. 
also use internships as a signal that they will require less training if hired than job seekers who have not done internships. The key insight is that, to be an effective signal, internships should differentiate employable from less employable candidates, that is, the signal should provide quality information, and what matters is the relative positioning in the job queue rather than absolute skill levels. ${ }^{19}$ The broad implications of this perspective are that internships effectively communicate information about applicant quality and should thus improve labour-market outcomes for high-quality applicants.

There is a research gap on the impact of internships on graduates' early career outcomes in Italy as a whole. Research focused on curricular internships undertaken during high school or HE in an Italian province showed that a significant share of internships is undertaken in industries characterized by low-skilled and highly repetitive jobs, such as trade and catering ${ }^{20}$ suggesting that internships may not be effective in skill acquisition. Other evidence, based on a study in the Italian information and communication technology (ICT) sector, found that internships did not act as a signal of employability and did not improve employment chances as might have been expected, possibly owing to the perceived short-term nature of the internships and to the lack of regulation regarding their content and duration. ${ }^{21}$ However, other research has found positive associations between internships and employment outcomes after graduation. ${ }^{22}$ Therefore, the nature of the association between internships and graduates' employment outcomes in Italy remains unclear.

In the UK, there is also limited research on how internships affect labour-market outcomes. Most of the literature tends to report on qualitative studies that focus on students' experiences of internships and perceptions of skills they developed, with the findings being broadly positive. ${ }^{23}$ However,

19 Valentina Di Stasio, Thijs Bol and Herman G Van de Werfhorst, 'What Makes Education Positional? Institutions, Overeducation and the Competition for Jobs' (2016) 43 Res Soc Stratification \& Mobility 53.

20 Lisa Dorigatti, Barbara Grüning and Carlo Fontani, 'Tra formazione e sfruttamento: Uno studio sui tirocini in Provincia di Bologna' in Rossana Cirillo (ed), Nuove frontiere della precarietà del lavoro: Stage, tirocini e lavoro degli studenti universitari (Società e trasformazioni sociali 2015).

21 Di Stasio (n 11).

22 AlmaLaurea, Condizione occupazionale dei laureati: XV indagine (AlmaLaurea 2013); Unioncamere, Ministero del lavoro, I fabbisogni occupazionali e formativi delle imprese italiane nell'industria e nei servizi per il 2012 (Unioncamere 2012), https:// www.cliclavoro.gov.it/Moduli\%20e\%20Documenti/excelsior_2012_sintesi_principali _risultati.pdf, accessed 30 March 2021.

23 Patricia Silva, Betina Lopes, Marco Costa, Dina Seabra, Ana I. Melo, Elisabeth Brito and others, 'Stairway to Employment? Internships in Higher Education' (2016) 72 Higher Educ 703. 
some of the quantitative research has cast doubt on the linkages between internships and labour-market outcomes, ${ }^{24}$ while other work has shown how different types of internships might reinforce existing inequalities and prevent social mobility. ${ }^{25}$ This evidence suggests that not all types of internships equally affect labour-market outcomes, and that individuals from more privileged backgrounds (for example, those with a higher level of economic, social and/or cultural capital, or holding higher credentials) are more likely to access the 'best' internships, and less privileged individuals may be less likely to do so, reproducing existing social inequalities.

Studies from other countries have tended to support the signalling perspective, where undertaking an internship provides a signal to potential employers about the motivation and commitment of the interns, positively affecting their employment opportunities. ${ }^{26}$ The subject of HE study and whether the internship is mandatory or voluntary also seem to play an important role. ${ }^{27}$ Qualitative studies have been mostly preoccupied with the type of skills that graduates can develop by undertaking an internship, complemented by the skills acquired during their study curriculum. ${ }^{28}$

In summary, the literature suggests that internships are broadly positively associated with labour-market outcomes, such as the probability of employment, a better job match and higher wages. However, there is a great deal of variation in the results, depending on the types of internships, labour-market

${ }^{24}$ Eg Nick Wilton, 'The Impact of Work Placements on Skills Development and Career Outcomes for Business and Management Graduates' (2012) 37 Stud Higher Educ 603.

${ }_{25}$ Charikleia Tzanakou, David Wilson and Kate Purcell, 'Internships as a Pathway to Employment for Graduates in the UK: An Agency-Structure Analysis?' (working paper, forthcoming); Holford (n 2); Wil Hunt and Peter Scott, 'Participation in Paid and Unpaid Internships among Creative and Communications Graduates' in Richard Waller, Nicola Ingram and Michael Ward (eds), Degrees of Injustice: Social Class Inequalities in University Admissions, Experiences and Outcomes (BSA/Routledge 2017).

${ }_{26}$ Weiss and others (n 2); Nils Saniter and Thomas Siedler, 'Door Opener or Waste of Time? The Effects of Student Internships on Labor Market Outcomes' (2014) IZA Discussion Paper No 8141, https://papers.ssrn.com/sol3/papers.cfm?abstract_id= 2432425\#\#, accessed 30 March 2021.

27 John Nunley, Adam Pugh, Nicholas Romero and Richard Seals, 'College Major, Internship Experience, and Employment Opportunities: Estimates from a Résumé Audit' (2016) 38 Lab Econ 37; Jack Gault, John Redington and Tammy Schlager, 'Undergraduate Business Internships and Career Success: Are They Related?' (2000) 22 J Marketing Educ 45.

${ }_{28}$ Eg Gay Crebert, Merrelyn Bates, Barry Bell, Carol-Joy Patrick and Vanda Cragnolini, 'Developing Generic Skills at University, During Work Placement and in Employment: Graduates' Perceptions' (2004) 23 Higher Educ Res \& Dev 147. 
outcomes and countries used in the studies. In general, most of the literature has been limited to national case studies, specific industries and disciplinary subject fields. With notable exceptions, ${ }^{29}$ there is a lack of multi-perspective cross-country studies on the impact of internships on graduates' early labour-market outcomes that account for internship heterogeneity.

\subsection{INSTITUTIONAL VARIATION AND CONTEXTUAL CONSIDERATIONS IN ITALY AND THE UK}

\subsubsection{Higher Education}

In the early 2000s, Italy reformed its HE system by introducing the so-called ' $3+2$ ' Bologna system. The new system, based on a two-cycle degree structure consisting of a first-level degree (Laurea Triennale, a three-year bachelor's-type degree) and a second-level degree (Laurea Magistrale, a two-year master's degree), replaced the programmes of the old system which lasted at least four years, although some programmes maintain a five- or six-year single cycle. In addition, there are single-cycle master's degrees (Laurea Magistrale a Ciclo Unico, five-year courses) for specific courses, such as law and medicine. Furthermore, there are vocational training programmes that can be accessed by Laurea Magistrale and Laurea Triennale holders, which are not part of the HE system and are not equivalent to a master's degree awarded in HE institutions. These vocational training programmes aim to provide skills relevant to specific occupations (such as human resources managers and technical occupations) and have their own specific transitional path. Figure 4.1 illustrates the simplified structure of the two-cycle Italian HE system.

In the UK, the typical HE two-cycle structure is a three- or four-year full-time undergraduate degree (some degrees, for example in medicine and dentistry, take longer), after which graduates join the labour market. Some undergraduate courses, in science and engineering-related fields in particular, offer an integrated master's degree. Master's courses typically last one or two years, and are often studied for professional purposes, ${ }^{30}$ although the proportion of graduates entering master's courses immediately after the bachelor's

29 Eg Kari P Hadjivassiliou, Emanuela Carta, Tom Higgins, Catherine Rickard, Suzanne Ter-Minassian, Flavia Pesce and others, Study on a Comprehensive Overview on Traineeship Arrangements in Member States: Final Synthesis Report (European Union 2012), https://op.europa.eu/en/publication-detail/-/publication/19623a37-37ee -4a60-b7ba-14a55526012f, accessed 30 March 2021.

30 Brenda Little, 'The UK Bachelors Degree: A Sound Basis for Flexible Engagement with an Unregulated Labour Market?' in Harald Schomburg and Ulrich 


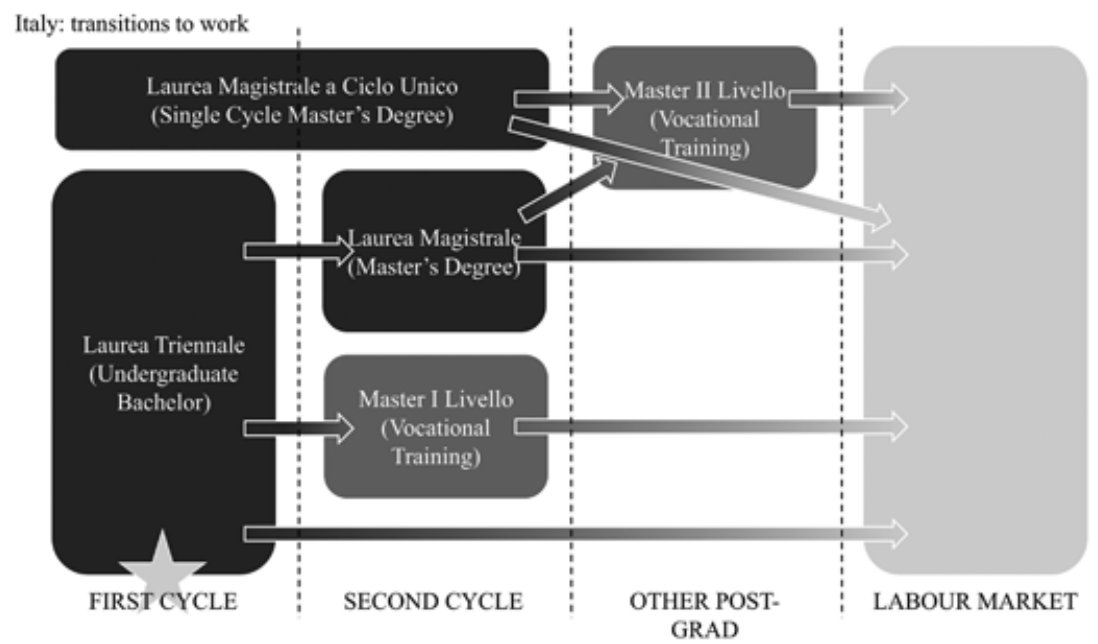

Note: The internship data in this chapter concern only the first cycle (internships that are undertaken by individuals who are students in higher education for their first degree, represented by the star).

Figure 4.1 The Italian two-cycle HE system and graduates' transitions to work

degree has been increasing. While vocational aspects have been present in UK HE for a long time, the role of work experience became prominent again from the 1990s onwards. ${ }^{31}$ Figure 4.2 illustrates the simplified structure of the two-cycle HE system in the UK.

The Bologna reform led to a noticeable expansion of HE in Italy, with the number of graduates entering the labour market doubling from around 174 000 in 2002 to around 326000 in $2018 .{ }^{32}$ During the years immediately after the ' $3+2$ ' reform, the Italian graduate labour market provided employment opportunities to the additional graduate workforce, ${ }^{33}$ but the situation deteri-

Teichler (eds), Employability and Mobility of Bachelor Graduates in Europe (Sense 2011).

31 Brenda Little and Lee Harvey, 'UK Work Placements: A Choice too Far?' (2007) 13 Tertiary Educ \& Manag 227.

32 Ministero dell'Istruzione, dell'Università e della Ricerca, 'Anagrafe nazionale degli studenti e deilaureati' (2019), https://anagrafe.miur.it, accessed 30 March 2021.

33 Giulio Bosio and Marco Leonardi, 'The Impact of Bologna Process on the Graduate Labour Market: Demand and Supply’ (2010) 69(3) Giornale degli Economisti e Annali di Economia 29. 


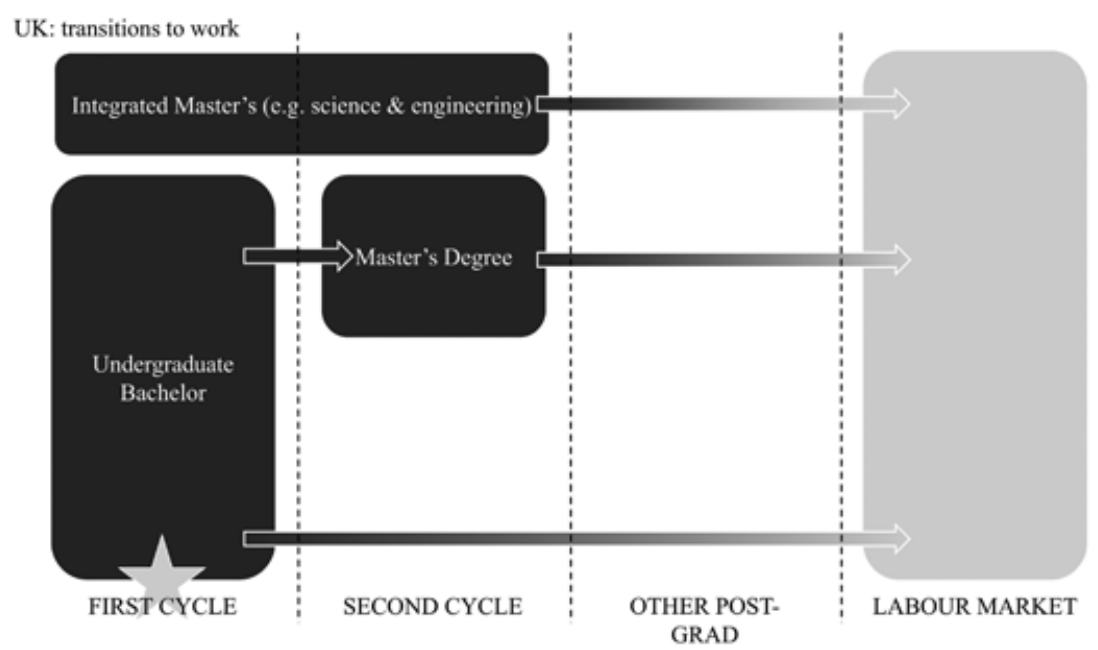

Note: The internship data in this chapter concern only the first cycle (internships that are undertaken by individuals who are students in higher education for their first degree, represented by the star).

Figure 4.2 The UK HE two-cycle system and graduates' transitions to work

orated after the outbreak of the financial crisis. ${ }^{34}$ In response, one of the strategies to facilitate university-to-work transitions was encouraging internship programmes both during studies and after graduation. As a consequence, an increasing number of degree courses introduced internships in their curriculum and awarded credits to participating students. With the shift from a one-cycle to a two-cycle education system, the share of graduates who undertook a curricular internship (an internship that is part of a programme of study) increased from 15 per cent in 2000 to 58 per cent in $2017 .^{35}$

In the UK, HE has expanded substantially over the past few decades. The number of graduates from all undergraduate programmes increased from around 350000 in $2001-02$ to just under 425000 in $2018-19 .{ }^{36}$ However, it

34 Maurizio Franzini and Michele Raitano, 'Few and Underutilized? Overeducation of Italian Graduates' in Emiliano Mandrone (ed), Labour Economics: PLUS Empirical Studies (Rubbettino 2012).

35 AlmaLaurea, Condizione occupazionale dei laureati: III indagine (AlmaLaurea 2001); AlmaLaurea, Condizione occupazionale dei laureati: XX indagine (AlmaLaurea 2018).

36 Higher Education Statistics Agency, Higher Education Student Statistics: UK, 2018/19 (HESA 2020) fig 2a, https://www.hesa.ac.uk/news/16-01-2020/sb255-higher -education-student-statistics, accessed 30 March 2021. 
is difficult to estimate the proportion of students participating in internships or placements during HE since there is a lack of comprehensive data. Some evidence suggests that there has been a decline in the number of undergraduate students taking up so-called 'sandwich' degree placements (sandwich degrees typically include a year-long placement/internship in industry, although the precise structure may vary): specifically, from just under 10 per cent in 1999-2000 to around 5 per cent in $2012-13,{ }^{37}$ although there is some suggestion that the number has increased since. ${ }^{38}$

A key issue in both countries is the relatively loose connection between the HE system and the labour market, ${ }^{39}$ whereby the field of study does not strongly determine the professions in which one might be employed. Although the Italian HE-labour market linkage has moved away from a tight coupling in recent decades, and has been described as 'loose', ${ }^{40}$ it arguably remains more centralized and more regulated than that of the UK. ${ }^{41}$ It is widely reported that in institutional configurations where the education-labour market link is strong, internships may be less important in affecting employment outcomes. In contrast, in institutional configurations where the education-labour market link is loose, internships may be more likely to affect employment outcomes, for example, because the educational system does not provide the full range of information required by employers. ${ }^{42}$ Thus, we expect the association between internships and labour-market outcomes to be stronger in the UK than in Italy.

\subsubsection{Labour-Market Context in Italy and the UK}

There are several main differences in the labour-market context between Italy and the UK. First, the rate of economic activity is lower in Italy (56 per cent) than in the UK (70 per cent) ${ }^{43}$ partly explained by the lower participation of women in the labour market in Italy. Second, the 2008 recession hit Italy more than it did the UK. While the unemployment rate was at similar levels in Italy

37 CM Jones, JP Green and HE Higson, 'Do Work Placements Improve Final Year Academic Performance or Do High-Calibre Students Choose to Do Work Placements?' (2017) 42 Stud Higher Educ 976.

38 Eg Mike Grey, 'The Placement Panacea' (Higher Education Policy Institute Blog, 11 April 2019), https://www.hepi.ac.uk/2019/04/11/the-placement-panacea/, accessed 30 March 2021.

39 Lore and Little (n 11); Little (n 11).

40 Schizzerotto and Barone (n 11).

41 Lore and Little (n 11).

42 Di Stasio and others (n 19); Valentina Di Stasio and Herman G van de Werfhorst, 'Why Does Education Matter to Employers in Different Institutional Contexts? A Vignette Study in England and the Netherlands' (2016) 95 Soc Forces 77.

${ }_{43}$ This is the 2017 labour force participation rate. 
and the UK in 2008 (6.7 per cent and 5.6 per cent, respectively), by 2014 it had almost doubled in Italy (12.7 per cent) but had only slightly increased in the UK (6.1 per cent) after peaking at 8.1 per cent in $2011 .{ }^{44}$ Third, youth unemployment is consistently higher in Italy than in the UK, both as a stand-alone rate and as a ratio of youth to adult unemployment rates, and this difference has increased since the recession (although the ratio of youth to adult unemployment has been converging during the past few years). In the UK, although youth unemployment increased from 15.0 per cent to 21.3 per cent between 2008 and 2012, the rates returned to pre-recession levels by 2015. However, in Italy, the youth unemployment rate more than doubled from 21.2 per cent to 42.7 per cent between 2008 and 2014. As a consequence, since the recession, Italian graduates have been facing substantial difficulties in finding their first job, arguably more than their counterparts in other countries. ${ }^{45}$ Yet, Italian graduates are still better off than Italian non-graduates, as they experience a higher probability of employment and a lower increase in the unemployment rate than their non-graduate peers during the same period. ${ }^{46}$

A key measure of graduate employment outcomes is the proportion of graduates working in graduate-level jobs. Although there are several ways of classifying jobs into graduate and non-graduate, in this chapter we use the term 'graduate jobs' for jobs that 'normally require knowledge and skills developed on a three-year university degree' to perform the job tasks in a competent way, following the definition and classification system developed by Elias and Purcell. ${ }^{47}$ In Italy, the share of graduates employed in non-graduate jobs lies between 23 per cent ${ }^{48}$ and 33 per cent, ${ }^{49}$ a disappointing rate that reflects the low proportion of graduate jobs demanded in the labour market. ${ }^{50}$ Data for

44 Here and in the rest of this paragraph, unemployment statistics are taken from Eurostat, 'Employment and Unemployment (LFS)' (2020), https://ec.europa.eu/ eurostat/web/lfs/data/database, accessed 30 March 2021.

45 Ibid.

46 AlmaLaurea, Condizione occupazionale dei laureati: XX indagine (n 35).

47 Peter Elias and Kate Purcell, 'Classifying Graduate Occupations for the Knowledge Society' (2013) Institute for Employment Research, University of Warwick Futuretrack Working Paper 5, 8. See also section 4.4 in this chapter.

48 Luca Cattani, Giovanni Guidetti and Giulio Pedrini, 'Overeducation among Italian Graduates: Do Different Measures Diverge?' (2018) 35 Economia Politica 491.

49 Andrea Ricci, 'Mis-match, percorsi di studio e condizioni produttive' in CNEL (ed), XX Rapporto su mercato del lavoro e contrattazione collettiva (Consiglio nazionale dell'economia e del lavoro 2018).

50 Francis Green and Golo Henseke, 'The Changing Graduate Labour Market: Analysis Using a New Indicator of Graduate Jobs' (2016) 5 IZA J Lab Policy 14; Francis Green and Golo Henseke, 'Graduates and "Graduate Jobs" in Europe: A Picture of Growth and Diversification' (2017) Centre for Global Higher Education Working Paper No 25. 
the UK suggest that around a third of graduates are employed in non-graduate jobs, which increases to around 50 per cent for recent graduates. ${ }^{51}$ Employers' demand for graduates has not kept up with its relative supply, which has led in turn to an increased emphasis on employability initiatives during HE, including an increase in the take-up of placements and internships. ${ }^{52}$ In this context, in the UK, internships and work experience are used to demonstrate work-readiness, and are widely encouraged and viewed as necessary by employers.

\subsubsection{Internships and Regulation of Internships in Italy and the UK}

There is evidence of a proliferation of internship types undertaken during HE in both the UK and Italy, together with loose regulation of these internships. Less than half of trainees aged 18-35 years in Italy (43 per cent) and in the UK (47 per cent) had their most recent traineeship based on a written traineeship agreement or contract with the host organization or company, whereas in the EU28, six out of ten respondents with traineeship experience (62 per cent) signed a formal traineeship agreement. ${ }^{53}$

In Italy, curricular internships undertaken during an undergraduate course can take place in a private firm, the public sector or the university. These internships can be optional or mandatory, depending on the course, but when students participate in either type of curricular internship, they need to acquire course credits to complete their degree. Moreover, curricular internships are always unpaid (except for very specific cases) and can take place either during or outside university term time.

In the UK, placements may be part of the HE curriculum as structured work placements, sandwich placements or other arrangements, depending on the type of course and subject studied. In most instances, the universities' role is mainly confined to advertising opportunities for industrial placements. It is usually students who are responsible for applying for and finding placements, often through personal contacts and networks. If students are unsuccessful in obtaining a placement, they may complete the degree without the industrial component. Some students may also undertake vacation internships which are not part of the HE curriculum. The existence of these different terms and their sometimes interchangeable use raises challenges in distinguishing between

51 Office for National Statistics, Graduates in the UK Labour Market: 2017 (Office for National Statistics 2017).

52 Phillip Brown and Anthony Hesketh, The Mismanagement of Talent: Employability and Jobs in the Knowledge Economy (Oxford University Press 2004).

53 European Commission (n 3). 
these different types of work experiences and their effects on labour-market outcomes.

In Italy, strict regulations apply only to HE-level apprenticeships leading to $\mathrm{HE}$ degrees, internships undertaken during school (secondary) education and internships undertaken after graduating from HE (the Fornero reform). Curricular internships that take place during HE are less centrally regulated. Italian universities are constitutionally entitled to establish their own regulations and have a high degree of autonomy in setting up their own rules to implement curricular internships. Usually, they issue broad guidelines which placement offices should refer to when signing specific agreements with employers' associations or single employers available to host trainees. These bilateral agreements thus constitute the main rules of reference for curricular internships in Italy, shaping their design, content and duration (including the training objectives and skills to be developed). This loosely regulated system, however, has raised increasing concerns among the academic community and policy-makers as the media has exposed instances of labour exploitation at the expense of young students and workers by their hosting organizations. ${ }^{54}$

In the UK, labour-market regulation around internships is a grey and complex area, as discussed in more detail in Chapter 6 of this volume. If an intern counts as a worker (if they are promised a contract of future work), they are entitled to the national minimum wage. However, students undertaking an internship lasting less than a year that is part of a higher or further education course based in the UK are not entitled to the minimum wage, though some may be paid at the employer's discretion. ${ }^{55}$ While student interns are excluded from minimum wage legislation, they are included in regulations regarding working time and health and safety. ${ }^{56}$ Individual HE institutions are responsible for ensuring the quality of their students' work placements and have their own internal quality assurance guidelines and procedures. At a national level, the Quality Assurance Agency for Higher Education has produced a code of practice on work-based learning. ${ }^{57}$ While not formally binding, HE institutions are expected to take the code of practice into account when developing their own guidelines. However, this code has been criticized for its limitations in the

\footnotetext{
54 Dorigatti and others (n 20).

55 UK Government, 'Employment Rights and Pay for Interns' (2019), https://www .gov.uk/employment-rights-for-interns, accessed 30 March 2021.

56 Stewart and others (n 7).

57 Quality Assurance Agency for Higher Education, Code of Practice for the Assurance of Academic Quality and Standards in Higher Education. Section 9: Work-Based and Placement Learning (QAAHE 2007), https://dera.ioe.ac.uk/4500/10/ PlacementLearning.pdf, accessed 30 March 2021.
} 
areas of learning content and transparency in hiring practices, and the lack of evidence regarding the effectiveness of these practices. ${ }^{58}$

\subsection{METHODOLOGY}

We draw our data from two longitudinal surveys of graduates' HE and labour-market experience: AlmaLaurea for Italy and Futuretrack for the UK. AlmaLaurea is a consortium of Italian universities that collects data about graduates' early career paths from 75 Italian universities (around 90 per cent of all graduates at the national level, $\mathrm{N}=109313$ for those graduating in 2009) at the time of graduation (a survey on the graduates' profile) and at one, three and five years after graduation (three surveys on the graduates' employment conditions). Futuretrack is a national longitudinal survey tracking those who applied in 2005-06 for full-time undergraduate degree programmes in the UK in four waves, from the point of application to HE in 2005-06 until 2011-12 when most will have graduated and will have been working in the labour market for 1.5 to 2.5 years. ${ }^{59}$ The Futuretrack survey sample size ranges from around 120000 in wave 1 to around 17000 in wave $4 .^{60}$

To facilitate comparative analysis between Italy and the UK, we focus on first-degree graduates who enrolled during 2005-06 and completed their studies during 2009-10, just as the impact of the financial crisis started to bite. The Futuretrack data are restricted to graduates who graduated during 2009-10, who had a bachelor's degree only, who were UK nationals and lived in the UK at the time of applying to $\mathrm{HE}$, and who did not study overseas $(\mathrm{N} \approx$ 9000), looking at their employment outcomes 1.5 to 2.5 years after graduation. The AlmaLaurea data are restricted to graduates who enrolled between 2005 and 2006 and graduated in 2009, and looks at graduates' employment outcomes one year after graduation $(\mathrm{N} \approx 48000)$.

We explore one main empirical question: how does doing an internship during undergraduate HE programmes affect labour-market outcomes for

\footnotetext{
58 Tom Higgins and Becci Newton, National Report on Traineeships UK (European Commission 2012).

59 Kate Purcell, Peter Elias, Gaby Atfield, Heike Behle, Ritva Ellison and Daria Luchinskaya, Transitions into Employment, Further Study and Other Outcomes: The Futuretrack Stage 4 Report (Institute for Employment Research, University of Warwick 2013).

${ }^{60}$ Although the surveys measure similar issues, they are not identical. For instance, Italian cohorts of surveyed graduates are selected based on the year of graduation rather than that of enrolment, which means there are important differences in age and years taken to complete their studies. Furthermore, AlmaLaurea only gathers information about internships and work experience during $\mathrm{HE}$ and/or at the time of graduation, not afterwards.
} 
graduates in the UK and Italy? To facilitate comparison of Italian and UK data, we use the Italian 'curricular internship' as the reference point, and include, for the UK, sandwich placements and structured work placements, which may be optional or mandatory, paid or unpaid, and usually take place during university term time. ${ }^{61}$ We broadly view these as 'curricular' internships. For the UK, we also include vacation internships in a firm, which are optional, can be paid or unpaid, and which usually take place outside of university term time. Vacation internships are widely considered internships in the UK, but we view them as 'open-market' rather than 'curricular' internships in the Broek and others framework. ${ }^{62} \mathrm{We}$ also include, for both countries, a variable proxying whether graduates did any paid work while at university, as an additional control.

The labour-market outcomes of interest in this study are (1) whether one is employed in a new job after graduation, (2) whether one is employed in a graduate job (SOC(HE)2010, using Elias and Purcell's classification ${ }^{63}$ ) and (3) the wage in their current job at the time of the survey. We also looked at factors affecting access to internships, although we do not report the findings here in detail. ${ }^{64}$

We estimated regression models for each of the three labour-market outcomes in each country. Whether one is in employment and whether one is working in a graduate job are binary variables $(1=$ yes, and $0=$ no $)$. In both countries, we measured wages using a multi-category variable that is well approximated by a continuous variable. We therefore used logistic specifications (analysis for Italy used probit specifications) for the dependent variables being in employment and working in a graduate job, and a log-linear ordinary least squares (OLS) model for the wage-dependent variable. The choice of the logistic estimator is justified by the binary nature of the response variable, while the OLS estimator is the typical econometric technique to estimate the wage equation when the dependent variable is continuous or can be assumed to be continuous.

In the absence of suitable longitudinal data, we cannot address the sample selection bias arising from the fact that we observed the probability of getting a job only for those graduates who are economically active, and that we

\footnotetext{
${ }^{61}$ For further discussion see Higgins and Newton (n 58).

62 Broek and others (n 4).

63 Elias and Purcell ( $\mathrm{n}$ 47). Note that for the graduate job variable Italian data are only available for five years after graduation, while UK data are available for the first job after graduation and for the job held at the time of the wave 4 survey.

${ }_{64}$ For comprehensive results, see Charikleia Tzanakou, Luca Cattani, Daria Luchinskaya and Giulio Pedrini, 'Access and Labour Market Outcomes of Internships During Higher Education in Italy and the United Kingdom' (AMS-Acta, University of Bologna 2020).
} 
observed the wage and the job type only for employed graduates. A typical correction is the well-known two-step estimator, ${ }^{65}$ which requires the identification of one or more exogenous exclusion restrictions to be used as regressors in the selection equation. As our data do not match this requirement, we decided to run the regressions within the subsample of employed graduates only. ${ }^{66}$ Nonetheless, thanks to the inclusion of a wide set of control variables, our estimates still provide valuable measures of association between types of internships and labour-market outcomes.

\subsection{RESULTS}

\subsubsection{Incidence of and Access to Internships in the UK and Italy}

A high proportion of the Italian respondents did either an internship (61 per cent) or paid work (68 per cent, see Table 4.1) during HE. The most frequent type of internship occurred in the public sector (37 per cent), followed by internships in a firm (33 per cent), while only a minority of students had interships within university premises (20 per cent). ${ }^{67}$ In the UK, around 20 per cent of participants did structured work placements, 11 per cent sandwich placements and 9 per cent vacation internships. Respondents could participate in more than one type of work-related activity. ${ }^{68}$ Almost 19 per cent of participants did no work-related activity at all (see Table 4.2). ${ }^{69}$

As regards access to internships, we found that, compared with women and individuals from lower socio-economic backgrounds, men from higher socio-economic backgrounds were more likely to access the types of internships associated with more positive labour-market outcomes. In particular, in

65 James J Heckman, 'Sample Selection Bias as a Specification Error' (1979) 47 Econometrica 53.

66 This methodology is considered acceptable since there would be a high correlation between the error terms of the selection and the main equation if the Heckman two-step procedure was chosen. In these cases 'Heckman's estimator is particularly inefficient and subsample OLS may therefore be more robust': Patrick Puhani, 'The Heckman Correction for Sample Selection and its Critique' (2000) 14 J Econ Surveys 53,65 .

${ }_{67}$ The remaining 9.6 per cent of respondents who did an internship did not provide any information on its type. Descriptive statistics and regression results for Italy are weighted.

${ }_{68}$ The percentage of cases refers to the percentage of respondents who mentioned undertaking this activity. Since this is a multiple response variable, the total frequency is greater than the number of cases, and the total percentage of cases is greater than 100 .

69 For the UK, we present unweighted and weighted descriptive statistics, and unweighted regression results. Our UK weighted regression analysis did not substantially affect the reported associations. 


\section{Table 4.1 Distribution of work-related activities done during study} (weighted), Italy ${ }^{a}$

\begin{tabular}{lcrr}
\hline Variable & Observations & Absolute frequency & $\begin{array}{r}\text { Relative frequency/mean } \\
\text { (std dev.) }\end{array}$ \\
\hline $\begin{array}{l}\text { Any type of internship } \\
\text { Internship in a firm }{ }^{\mathrm{b}}\end{array}$ & 48058 & 29320 & $61.01 \%$ \\
$\begin{array}{l}\text { Internship with } \\
\text { a university }\end{array}$ & 29320 & 9746 & $33.20 \%$ \\
$\begin{array}{l}\text { Internship in the } \\
\text { public sector }\end{array}$ & 29320 & 5815 & $19.83 \%$ \\
$\begin{array}{l}\text { Length of the } \\
\text { internship (hours) }\end{array}$ & 29320 & 10856 & $37.03 \%$ \\
Paid work & 48058 & 29320 & $466.18(1044.36)$ \\
\hline
\end{tabular}

Notes:

${ }^{\text {a }}$ All variables are weighted in order to refer the sample to the population of reference.

${ }^{\mathrm{b}}$ These variables are observed only if the graduate has undertaken an internship $(\mathrm{N}=29320)$.

Table 4.2 Distribution of work-related activities done during study allowing for multiple responses (unweighted and weighted), $U K$

\begin{tabular}{|c|c|c|c|c|c|}
\hline \multirow[t]{2}{*}{ Type of work-related activity } & \multirow[t]{2}{*}{ Freq. } & \multicolumn{2}{|c|}{ Unweighted } & \multicolumn{2}{|c|}{ Weighted } \\
\hline & & $\begin{array}{l}\% \text { of } \\
\text { responses }\end{array}$ & $\%$ of cases & $\begin{array}{l}\% \text { of } \\
\text { responses }\end{array}$ & $\begin{array}{l}\% \text { of } \\
\text { cases }\end{array}$ \\
\hline $\begin{array}{l}\text { A sandwich-year undergraduate } \\
\text { placement }\end{array}$ & 989 & 7.39 & 10.84 & 7.57 & 10.90 \\
\hline $\begin{array}{l}\text { One or more shorter structured work } \\
\text { placement(s) integral to course }\end{array}$ & 1813 & 13.54 & 19.88 & 14.91 & 21.47 \\
\hline $\begin{array}{l}\text { Assessed project work in external } \\
\text { organization as part of course }\end{array}$ & 650 & 4.85 & 7.13 & 5.31 & 7.64 \\
\hline Vacation internship with an employer & 807 & 6.03 & 8.85 & 4.83 & 6.96 \\
\hline Paid work & 4968 & 37.11 & 54.47 & 35.51 & 51.14 \\
\hline $\begin{array}{l}\text { Unpaid work undertaken to gain useful } \\
\text { career-related experience }\end{array}$ & 2275 & 16.99 & 24.94 & 16.50 & 23.77 \\
\hline Other work-related activity & 119 & 0.89 & 1.30 & 0.87 & 1.25 \\
\hline None of the above & 1713 & 12.79 & 18.78 & 14.07 & 20.27 \\
\hline $\begin{array}{l}\text { Voluntary work, no information } \\
\text { whether career related }\end{array}$ & 55 & 0.41 & 0.60 & 0.43 & 0.61 \\
\hline Total & 13389 & 100.00 & 146.79 & 100.00 & 144.01 \\
\hline
\end{tabular}

Note: Valid cases 9121; missing cases 19. 
the UK social class still plays a significant role in affecting access to the best internship opportunities, whereas in Italy it was gender as well as student performance that affected participation in the most effective internships.

\subsubsection{Do Internships during HE Affect Labour-Market Outcomes in the UK and Italy?}

Evidence from Italy suggested that doing any curricular internship did not tend to improve the employability of recent graduates in the labour market, whereas the UK experience showed more positive results (see Table 4.3). However, in Italy, undertaking an internship within a firm was associated with an increase in the probability of finding a job after graduation. This positive relationship was confirmed when controlling for the interaction term between an internship within a firm and paid work, which was not significant. Thus, doing an internship within a firm and doing paid work enhanced the probability of employment; however, there was no additional benefit gained from doing both activities. We thus observe substitutability rather than complementarity between doing an internship within a firm and paid work. In contrast, in the UK, our analysis shows that sandwich placements and, to a lesser extent, vacation internships and structured work placements were positively associated with the probability of being in employment.

Undertaking an internship did not affect the likelihood of working in a graduate job (five years after graduation) in Italy. However, in the UK, doing a sandwich placement, a vacation internship or a structured work placement was positively associated with working in a graduate job. ${ }^{70}$ Unfortunately, we cannot say whether the findings arise owing to the effect of internships, or to the temporal difference in the data.

Finally, in Italy there was no significant effect of internships on wages, but in the UK undertaking sandwich placements was associated with a 15.5 per cent increase in wages (around 1.5 to 2.5 years after graduation), structured work placements with a 7.0 per cent increase and a vacation internship with a 21.4 per cent increase. Paid work during HE was associated with small increases in wages in both Italy ( 2.7 per cent) and the UK (4.6 per cent).

\subsection{CONCLUSIONS AND IMPLICATIONS FOR INTERNSHIP REGULATION}

We found that comparing graduates' early career outcomes in two different institutional contexts highlights the importance of having a clear definition

70 Results are available on request. 
Table 4.3 Comparison of the association between undertaking an internship and the probability of being in employment and wages in Italy and the UK

\begin{tabular}{|c|c|c|c|c|c|c|}
\hline & \multicolumn{3}{|c|}{$\begin{array}{c}\text { Employment (probability of getting } \\
\text { a job after graduation) })^{\mathrm{a}}\end{array}$} & \multicolumn{3}{|c|}{ Wages in current job } \\
\hline & Italy & Italy & UK & Italy & Italy & UK \\
\hline \multirow[t]{2}{*}{ Internship (any type) } & 0.0257 & & & 0.0059 & & \\
\hline & $(0.0585)$ & & & $(0.0114)$ & & \\
\hline \multirow[t]{2}{*}{ Internship within a firm } & & $0.0598 * * *$ & & & 0.0144 & \\
\hline & & $(0.0886)$ & & & $(0.0142)$ & \\
\hline \multirow[t]{2}{*}{ Paid work } & $0.0569 * * *$ & $0.0654 * *$ & $0.048 * * *$ & $0.0272 * * *$ & $0.0269 * * *$ & $0.046^{* *}$ \\
\hline & $(0.0759)$ & $(0.0756)$ & $(0.008)$ & $(0.0089)$ & $(0.0089$ & $(0.015)$ \\
\hline A sandwich-year & & & $0.063 * * *$ & & & $0.155^{* * *}$ \\
\hline undergraduate placement & & & $(0.015)$ & & & $(0.023)$ \\
\hline One or more shorter & & & $0.031 *$ & & & $0.070^{* *}$ \\
\hline structured work & & & $(0.014)$ & & & $(0.022)$ \\
\hline \multirow{2}{*}{\multicolumn{7}{|c|}{$\begin{array}{l}\text { placement(s) integral to } \\
\text { course }\end{array}$}} \\
\hline & & & & & & \\
\hline A vacation internship with & & & $0.037 *$ & & & $0.214 * * *$ \\
\hline an employer ${ }^{\mathrm{b}}$ & & & $(0.016)$ & & & $(0.024)$ \\
\hline $\begin{array}{l}\text { Controls (vary slightly } \\
\text { between UK and Italian } \\
\text { data) }\end{array}$ & \multicolumn{6}{|c|}{$\begin{array}{l}\text { Type of high school, age, living area, area of study, type of HE institution, } \\
\text { Italian citizenship, internal migrant, study period abroad, father's occupation, } \\
\text { average mark, years to get the degree, degree classification }\end{array}$} \\
\hline $\mathrm{N}$ & 10409 & 10409 & 6018 & 7665 & 7665 & 5265 \\
\hline \multirow{2}{*}{$\begin{array}{l}\text { Pseudo- } R^{2} \\
\text { (Wage regression: } R^{2} \text { ) }\end{array}$} & 0.0892 & 0.0903 & 0.068 & 0.5972 & 0.5973 & 0.261 \\
\hline & \multicolumn{3}{|c|}{$\begin{array}{l}\text { Marginal effects at the mean, probit } \\
\text { (Italy), Average marginal effects, } \\
\text { logit (UK), robust standard errors in } \\
\text { parentheses. }{ }^{*} \mathrm{p}<0.05, * * \mathrm{p}<0.01 \text {, } \\
* * * \mathrm{p}<0.001\end{array}$} & \multicolumn{3}{|c|}{$\begin{array}{l}\text { Log-linear OLS coefficients, standard } \\
\text { errors in parentheses. Regression on } \\
\text { subsample of employed graduates. } \\
* \mathrm{p}<0.05,{ }^{*} \mathrm{p}<0.01,{ }^{* * *} \mathrm{p}<0.001\end{array}$} \\
\hline
\end{tabular}

Notes:

Regressions for Italy are weighted by respondents' individual coefficients provided by the data collector (AlmaLaurea). Regressions for UK are unweighted (weighted regressions were also conducted but did not substantially affect the results).

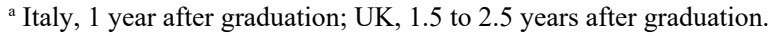

${ }^{\mathrm{b}}$ The effect of a vacation internship on the likelihood of employment was not significant in the UK weighted regressions; all other associations remained significant.

of internships to distinguish them from other types of work experience within and beyond national and institutional boundaries. What we counted as an internship in Italy was slightly different from the UK definition. An agreed 
and detailed definition would enable us to compare internships in a meaningful and comprehensive way, and enhance our academic understanding of this phenomenon.

In summary, we have shown that internships in both the UK and Italy have a positive effect on being employed after graduation, and in the UK they also have a positive effect on wages. In Italy, we found this positive effect only if the internship was undertaken within a firm. We found no evidence that internships positively affect the probability of obtaining a graduate job in Italy, but some evidence for this in the UK. This complements the results we reported in a working paper: that social class plays a significant role in shaping access to the 'best' internship opportunities (that is, associations with labour-market outcomes) in the UK, whereas in Italy participation in the 'best' internships is substantially gendered. ${ }^{71}$

While we found more positive outcomes associated with internships in the UK than in Italy, we argue that the particular way in which we operationalized and measured labour-market outcomes captured only a part of the overall benefits of internships. We cannot report on less tangible qualitative benefits of internships, such as individuals' experience of work in specific sectors, occupations and organizations, or how students make informed career-related decisions. $^{72}$ We need to consider more broadly the skills, experience and knowledge gained from undertaking an internship, even if this is not directly reflected in the better job outcomes that we chose to look at.

We do offer a word of caution: our analysis appears to support the argument for the signalling role of internships, with the implication that, if internships become curricular and compulsory, the signal they send may become diluted. ${ }^{73}$ That is, from the economic signalling perspective, increasing the accessibility of internships has a trade off with labour-market outcomes (for example in terms of wages) since employers can no longer use the internship as a reliable signal of applicant quality or job readiness. However, we argue that the economic perspective is not the only way to look at this issue. A wealth of evidence suggests that internships help students decide what they want to do and develop a wide range of skills, thus, it is still useful to improve access to internships in general. Yet, the extent to which graduates benefit from intern-

71 Tzanakou and others (n 64).

72 Kate Purcell, Peter Elias, Anne Green, Gaby Atfield, Arlene Robertson, Noel Whiteside and others, Present Tense, Future Imperfect? Young People's Pathways into Work (Institute for Employment Research, University of Warwick 2017), https:// warwick.ac.uk/fac/soc/ier/research/pathways/presenttensefutureimperfect_final.pdf, accessed 30 March 2021.

73 Eg Weiss and others (n 2). 
ships is partly hampered by the uncertainty stemming from the loose regulation of these activities.

Furthermore, the Italian findings on the lower effectiveness of internships on graduates' labour-market outcomes compared with the situation in the UK should be viewed in the context of the growing number of graduates combined with the major demand-side shock that occurred during the 2008-09 financial crisis. In Italy, that crisis potentially contributed to the labour market's inability both to absorb the additional supply of graduates, and to offer high-quality curricular internships to HE students. Curricular internships are characterized by a persisting loosely regulated regime, where working time, pay and skills content are defined by bilateral agreements in which these dimensions vary greatly depending on the relative bargaining power deployed by universities and hosting organizations, failing to secure a clear and consistent set of training objectives. In both countries, there is a need for an explicit regulatory framework for curricular internships which should include explicit information about the content, duration, pay and supervision to ensure that these internships are of high quality and are not exploitative and/or of limited use for HE students. ${ }^{74}$

Our research thus reinforces the significance of regulations that will ensure recruitment for internships is open and transparent to avoid reproducing structured inequalities in the labour market (for example, along gender and socio-economic background lines). Furthermore, to enable all students (irrespective of their socio-economic background) to access opportunities that could be instrumental in furthering their career, regulations should protect less privileged individuals, for instance, through access to state-funded bursaries or through introducing a minimum wage for all interns. Support should also extend to firms that are less able to pay their interns and/or to train them properly. The cost to government of doing this should be carefully contrasted with the potential broader social and economic gains made through improved youth employment outcomes.

Further research is needed to understand the meaning and role of internships in different countries. Otherwise, we run the risk of discussing different types of work experience in different contexts, leading to seemingly positive outcomes across the board, without exploring why this might be the case.

74 Roberts (n 2); Stewart and others (n 7). 